\title{
CURRICULUM IMPLEMENTATION \\ INTEGRAL EDUCATION BASED ON TAUHID \\ (Case Study of Curriculum Implementation in SMA Luqman Al Hakim Surabaya)
}

\author{
D.M. Zakariya \\ dinmzakariya70@gmail.com
}

\begin{abstract}
This study aims to explore how the design of Integral based Tauhid Education curriculum in SMA Luqman Al Hakim Surabaya, how to implement it, and how to improve the quality of education. The type of approach in this study is descriptive qualitative, as the direction of the type of qualitative research, then the data collected were analyzed to obtain various interpretative descriptions according to the logical and rational scientific research rules on the data collected. The results of this study can be summarized as follows. 1) The curriculum of Tauhid-Based Integral Education in SMA Luqman Al Hakim Surabaya is a blend curriculum of curriculum 2013. 2) The implementation of Tauhid-Based Integral Education Curriculum using three approaches that serve as references, first, Tilawah Method, second, Tazkiyah Method, and Third, Ta'limah Method. Curriculum development contains three characteristics, namely politeness priority before science, thorough and aligned, and back to nature. The implementation of the Tauhid-Based Integral Curriculum in SMA Luqman Al Hakim Surabaya is described in the structure and content of the curriculum, setting the learning load and time allocation, learning completeness, appraisal system, increase, graduation, and life skills education. 3. The implementation of Tauhid-Based Integral Education Curriculum in improving the quality of education in SMA luqman Al Hakim Surabaya, through the preparation of human resources who have qualifications in their field and have the spirit to preach through education. The three characters of the students' output from the curriculum of TauhidBased Integral Education are, first Taqwa, second Intelligent, and third independent.
\end{abstract}

Keywords: Curriculum Implementation, Integral Education, Tauhid-Based

\section{A. INTRODUCTION}

The success of a nation can be reflected from its education system, the better the education system of a nation the prestigious human will be produced, high morality, have proficiency in various fields of science, able to apply

\footnotetext{
${ }^{1}$ Muhammad Hambal. 2018. Halaqah Tradition in Building Rabbani Characters in Pesantren
}

and skilled in solving life problems that they faced. ${ }^{1}$

It is an undeniable reality that countries are experiencing a humanitarian crisis. According to Thomas Lickona's research there are 10 signs of a nation that will experience decline and destruction; 1) Destructive

Al-Islam Lamongan, East Java, Indonesia. Jurnal Studia Religia, Vol. 2, No. 1. 
behaviors among adolescents are increased, 2) the use of words that tend to worsen such as mockery, insults and reproaches, 3 ) the influence of friends is much stronger than parents or teachers, 4) The increased of abusing sex, smoking and illegal drugs behavior on teenagers, 5) the decline in moral behavior and increased personal egoism, 6) decreased pride, love of the nation and homeland, 7) lack of respect for others, parents and teachers, 8) increased damaging behavior to the public interest, 9) dishonesty happened everywhere, 10) growing suspicion, hate and hostility among citizens. ${ }^{2}$

National education is experiencing anxiety, various problems hit as if it is difficult to solve. Unity that has been able to expel the occupation was similarly as if it devastated by personal interests or groups. Systematically it happens from the political elite to the lower society. This can be seen by the increasing vulnerability of the political elite, the vulnerability of young people's personalities, to the insecurity of social structures. $^{3}$

The occurrence of demoralization that befell the society especially teenagers as the result of Puslitkes University of Indonesia (UI) research and National Narcotics Agency (BNN) about 27.32 percent of drug users in Indonesia come from among high school students and university students. The number is likely to increase due to the release of new types of drugs. ${ }^{4}$

It must be admitted that this issue is a general picture of national education failure, because the education system offered is still partial. There are at least three major groups of output

${ }^{2}$ Hari Santoso, Fitrah Basad

Education,(Bekasi, Yayasan Cahaya Mutiara Timur,2015).57 prototypes of education from the results of partial systems, namely: first, they have the intellectual ability to master the latest technology, but less able to live the noble values of religious teachings. Second, able to master and live the noble values of religious teachings but not able to master the technology and political dynamics that are in it. Third, able to master the teachings of religion intellectually but not able to live the noble values of religious teachings so they pawn the religion in daily practice. ${ }^{5}$

It becomes the challenge of educational institutions to prepare a comprehensive integral education, which is able to provide the provision of world life and the hereafter, following the development of science and technology and give IMTAQ strengthening.

SMA Luqman Al Hakim Surabaya is an educational institution in Surabaya that has an integral curriculum based on Tauhid, which combines worldly education and hereafter in balance.

The next question that needs to be answered is how to design an integral curriculum based on Tauhid, how to implement it, and how to improve the quality of education.

\section{B. RESEARCH METHOD}

1. Research Approach and Types

The type of this research is field research and the approach used is descriptive qualitative. Bodgan and Taylor define a qualitative methodology as a research procedure that produces descriptive data in the form of written or

\footnotetext{
${ }^{3}$ Samsul Nizar, sejarah pendidikan

Islam,(Jakarta: Kencana, 2009)

${ }^{4}$ Republika.co.id, rabu, 03 januari 2018

5 Samsul Nizar.
} 
oral words of people and observable behavior. ${ }^{6}$

2. Research Subject

The research subject as presented by Spradley, is a source of information. While Moleong suggested that the subject of research is insiders in the research background, i.e. people who are used to provide information about the situation and conditions of research background. $^{7}$

In this study the author choose the subject of research at SMA Luqman Al Hakim Surabaya based on the grounds that this institution has and organizes a curriculum based on tauhid. The subjects of his research are the principal, the boarding school attendant, the vice of curriculum, the teacher and the school stakeholder in Luqman $\mathrm{Al}$ Hakim High School Surabaya.

3. Types and Data Sources

a. Type of Data

Lofland divided the type of data into main data and additional data, ${ }^{8}$ or according to Suryadi Suryabrata it is called as primary data and secondary data. ${ }^{9}$

1) Primary data is a direct data that is collected by researchers from the first source such as the Principal, Head of Care and Cadre, vice of Curriculum as a policy maker in the planning of Tauhidbased curriculum.

2) Secondary data is data collected by the researcher as a supporter from the first source. This data is in the form of school documents such as the geography of the school, school profile, guidebook and so forth.

3) The type of data used in this study is qualitative data. Because the data can be

\footnotetext{
${ }^{6}$ Basrowi dan Suwandi, Memahami Penelitian Kualitatif( Jakarta: Rineka Cipta, 2008),21.

${ }^{7}$ Ibid,188.

${ }^{8}$ Ibid,169.

${ }^{9}$ Suryadi Suryabrata, Metodologi,84.
}

measured indirectly means not using numbers but using words or sentences. ${ }^{10}$ b. Data Sources

Source of data in this study is the subject from which data can be obtained. In this study the authors used data sources in the form: ${ }^{11}$

1) Person (resource person), i.e. data sources that can provide data in the form of oral answers through interviews or written answers through questionnaires. In this case the authors obtain the data or information about the general description of the object of research and implementation of curriculum based on tauhid in Senior High School integral school Luqman Al Hakim Surabaya from Kadik Dasmen (head of services for elementary and high school), foundation administrators, headmaster, heads attendant of care and cadre, vice curriculum, administrative sections, and school stakeholders because the resource persons are very needed by the authors to smooth this thesis.

2) Place (location), i.e. data source that presents the appearance of a state, using the observation method in SMA luqman Al Hakim Surabaya, such as geographical location, headmaster's room, classroom, teachers' room, administrative room and so forth.

3) Paper (document/archive), i.e. data source that presents signs in the form of letters, numbers, drawings, or other symbols in SMA luqman Al Hakim Surabaya such as students' data, teachers' data, organizational structure, school curriculum documents, curriculum structure, etc.

4. Data Collection Method

\footnotetext{
${ }^{10}$ Sutrisno Hadi, Metodologi Research, jilid 1(Yogyakarta : Andi Offset, 1995),66.

${ }^{11}$ Suharsimi Arikunto, Prosedur Penelitian

Suatu Pendekatan Praktik( Jakarta: PT.Rineka Cipta,2002),107.
} 
To obtain clear, precise and complete information then the author used several methods, among others:

a. Observation Method

This method is used to directly see and observe the conditions in the field so that researchers get a broader picture of the problems studied. ${ }^{12}$

In this study the authors made direct observations about the activities undertaken by the relevant parties and about the general view of the scope of SMA Luqman Al Hakim Surabaya, as well as matters relating to the concept and application of an integral school.

b. Interview / Interview Method

Interviews are widely used in qualitative research, it may even be said to be the primary data collection technique. ${ }^{13}$

In this study, the authors conduct a direct or indirect interviews to the parties related to the problems of Tauhid-based curriculum and its implementation in SMA luqman $\mathrm{Al}$ Hakim Surabaya, such as: Principals, administrative departments and school stakeholders to obtain complete and accurate data.

c. Documentation Method

Documentation method is a means of collecting data that produces important records related to the research problem, so that will be obtained complete, valid and non under estimates data. ${ }^{14}$

In this study, the authors collected data related to the location which is observed and the problems that became the focus of research from existing documents in SMA Luqman $\mathrm{Al}$ Hakim Suabaya such as organizational structure, guidebook, curriculum

\footnotetext{
${ }^{12}$ Basrowi dan Suwandi, Memahami Penelitian, 93-94.

13 Nana Syaodih Sukmadinata, Metode Penelitian Pendidikan (Bandung : PT.Remaja Rosdakarya,2012),217.
}

documents, work program, teacher data, students and so forth.

\section{Data Analysis}

Data analysis in descriptive qualitative research and process of searching and arranging systematically the data obtained from interviews, field notes, and documentation, by organizing data into categories, describing into units, synthesizing, arranging into patterns, choosing which are important and which will be learned and make the collection so easy to be understood by yourself and others. ${ }^{15}$

The data in this research is essentially in the form of words, sentences or paragraphs which is stated in and expressed in the form of descriptive narrative of occurring events and experienced within the scope of SMA Luqman Al Hakim Surabaya.

\section{RESULT AND DISCUSSION}

SMA Luqman $\mathrm{Al}$ Hakim is one of the units of Hidayatullah Boarding School Surabaya which was established on July 18, 1994, located on J1. Kejawan Putih Tambak VI/1, District Kejawan Putih Tambak, Subdistrict Mulyorejo, Surabaya.

The integral educational institutions emerge in Hidayatullah Boarding School among the intention to provide solutions for the completion of the problems of honor. The multidimensional crisis occurring in this religious community is also contributed by an educational system that no longer refers to Islamic education and tends to be secular resulting in materialistic, liberal and hedonist output.

The above facts, made Hidayatullah's pioneers realize to present

\footnotetext{
${ }^{14}$ Basrowi dan Suwandi, Memahami penelitian, 158.

${ }^{15}$ Sugiyono, Metode penelitian Kombinasi/ mixed Methods I ( Bandung : Alfabeta, 2012 ), 333.
} 
an integral educational institution (Tauhid) which is characteristic of Islam, with professional and modern management. With the hope is to produce insan kamil (good human). That is the man who is able to place himself as Abdullah and portray himself as the khalifah of Allah in life. ${ }^{16}$

Integral School Vision "Excellent With Integral Character"

Vision Indicators of Students' Output Profile in Luqman Al Hakim High School:

1) Excellent in the spiritual field of Islam

a) Toward the Strong Tauhid

b) Qur'ani well-mannered

c) Worshiping Diligently

d) Da'wah Actively

2) Excellent in the mastery of the Qur'an

3) Excellent in Arabic and English

4) Excellent in the field of Academic and Life Skill

5) Excellent in the field of

Environmental Management

a. Mission of Integral School:

1) Holding a professional integrity institution based on monotheism, giving birth to a Taqwa generation, smart, independent, achievement and global perspective.

2) Priority exemplary, affection and professionalism in the education process.

3) Develop an integral environment that is islam, scientific and natural.

4) Organizing executive school management system and services.

The Content Standard developed by SMA Luqman Al Hakim refers to five components: (1) curriculum development (2) curriculum structure (3) Studying learning arrangements (4) guiding and counseling services (5)

${ }^{16}$ Tim DPP Pendidikan Hidayatullah, Konsep Sekolah Integral, (Jakarta : DepDik Hidayatullah, 2001) extra-curricular activities. Curriculum Structure of SMA Luqman Al Hkaim is structured and established based on Permendiknas and leading programs. Featured programs developed include: (1) Tahfidz Alquran Program, (2) Olympic Program, (3) Research Science Program (4) National Exam Preparation Program, (5) Arabic and English Language Development Program, and (6) Extracurricular Interest and Talent Development Program. The leading programs we developed in order to prepare learners for the implementation of AFTA or ASEAN Economic Community (MEA), so that high school Luqman Al Hkaim Surabaya can produce output profile that can compete in the globalization era.

1) Boarding School Educational Pattern Based on Tauhid

The process of learning and transformation value makes the mosque as the center of activity and symbol of Islamic spiritual character that makes all aspects of students in a boarding school focused on the love and greatness of Allah SWT.

2) Learning System of Boarding and Full day School

The location located within Pondok Pesantren Hidayatullah Surabaya is a strategic and conducive to support the learning process that is effective and fun. With the boarding system and full day school then the concept of enforcing Islamic law in an effort to build a miniature of Islamic civilization is very easy to implement.

3) Al-Qur'an and Science Education System.

Learning is done by integrating elements of the Qur'an and intellectuals that focus on the formation of morality and logical, systematic, structured, and 
analytical thinking patterns using problem solving approach.

4) Schools that provide quality assurance (quality assurance) to alumni, received at the favorite universities at home and abroad (science and diniyah)

5) Characteristics of educators/teachers and young education personnel, energetic, have a high willingness and commitment supported by the pattern of cadre based on the systematic decline of revelation (Al Qur'an and $\mathrm{Al}$ Hadith).

6) The only one Senior High School that is located within the Hidayatullah Boarding School Surabaya with adequate facilities and infrastructure to support the boarding school programs and Full day.

7) Become the main campus and pilot project school in Hidayatullah environment nationally.

8) Support of santri guardian/parents and all stakeholders who give enough support to the implementation of school and boarding school programs.

\section{CONCLUTION}

Based on the research results that has been described then it can be concluded that:

1) Design of Tauhid-Based Integral Curriculum

Curriculum implemented by SMA Luqman Al Hakim Surabaya is a combination of 2013 curriculum and the characteristic curriculum of the school, which is inspired by the revelation (SW) which is the preaching method based on the orderly nuzul revelation that was originally revealed to Prophet Muhammad SAW, Surat al-'Alaq (Tauhid based), Al qolam (Islamic principal), Al-Muzzammil (Tazkiyah and Worship), Al-Mudatsir (principles of tarbiyah and da'wah) and Al-Fatihah (the concept of civilization, the concept of Kaffah Islam).
2) Implementation of Integral Curriculum Based on Tauhid

The implementation of Luqman $\mathrm{Al}$ Hakim high school curriculum implementing the Tauhid Based Curriculum Operational Methodology includes:

a. Apply Systematic Revelation in education and learning.

b. The unit of education process is done through Tilawah, Tazkiyah and Ta'limah.

c. The core of all material is based on Alqur'an and As-Sunnah.

And there are three main characters that must be implemented in Tauhid-Based Integral Education namely:

a. Prioritize preaching before science

b. Thorough and harmonious

c. Back to nature

3) Implementation of Tauhid-Based Integral Education Curriculum in Improving the Quality of Education in SMA Luqman Al Hakim Surabaya Implementation of Integral Education Curriculum in Improving the Quality of Education in SMA Luqman Al Hakim Surabaya is by doing various efforts, among which the most important is the human resources that implement the curriculum is looking for teachers who have qualifications in their field and have the spirit to preaching in the field of education, such as in Al Qur'an field by presenting Sheikh from Middle East, diniyah field from LIPIA and general field of teachers and senior tutor.

The expected output profile of the curriculum implementation is to print a cadre of Taqwa, Smart and Independent.

\section{REFERENCES}

Arikunto, Suharsimi. Prosedur Penelitian Suatu Pendekatan 
Praktik. Jakarta: PT.Rineka Cipta. 2002.

Basrowi and Suwandi. Memahami Penelitian Kualitatif. Jakarta: Rineka Cipta. 2008.

Hadi, Sutrisno. Metodologi Research. jilid 1. Yogyakarta: Andi Offset. 1995.

Hambal, Muhammad. 2018. Halaqah Tradition in Building Rabbani Characters in Pesantren Al-Islam Lamongan, East Java, Indonesia. Jurnal Studia Religia, Vol. 2, No. 1.

Hidayatullah, DPP, Pendidikan, Departemen, Tim, Konsep Sekolah Integral. Jakarta: Depdik Hidayatullah. 2001.

Nizar, Samsul. Sejarah Pendidikan Islam. Jakarta: Kencana. 2009.

Santoso, Hari. Fitrah Basad Education. Bekasi: Yayasan Cahaya Mutiara Timur. 2015.

Sugiyono. Metode penelitian Kombinasi/ mixed Methods I. Bandung: Alfabeta. 2012.

Sukmadinata, Nana Syaodih. Metode Penelitian Pendidikan. Bandung: PT.Remaja Rosdakarya. 2012.

Suryabrata, Suryadi. Metodologi penelitian. Jakarta: Raja Grafindo Persada. 1998.

Suryosubroto, Tata Laksana Kurikulum. Jakarta: Rineka Cipta. 1990. 